\title{
Potential of AM Fungi in Phytoremediation of Heavy Metals and Effect on Yield of Wheat Crop
}

\author{
Asif Khan', Muhammad Sharif', Amjad Ali2 ${ }^{*}$, Syed Noor Muhammad Shah ${ }^{3,4}$, \\ Ishaq Ahmad Mian1, Fazli Wahid1, Bismillah Jan1, Muhammad Adnan1, \\ Shah Nawaz ${ }^{1}$, Nisar Ali ${ }^{1}$ \\ ${ }^{1}$ Department of Soil and Environmental Sciences, University of Agriculture, Peshawar, Pakistan \\ ${ }^{2}$ College of Resource and Environment, Northwest A\&F University, Yangling, China \\ ${ }^{3}$ Department of Horticulture, Gomal University, Dera Ismail Khan, Pakistan \\ ${ }^{4}$ College of Horticulture, Northwest A\&F University, Yangling, China \\ Email: amjadali@aup.edu.pk
}

Received 18 March 2014; revised 17 April 2014; accepted 29 April 2014

Copyright (C) 2014 by authors and Scientific Research Publishing Inc.

This work is licensed under the Creative Commons Attribution International License (CC BY).

http://creativecommons.org/licenses/by/4.0/

(c) (i) Open Access

\begin{abstract}
A pot experiment was conducted to determine the potential of AM fungi in phytoremediation of heavy metals and its effect on yield of wheat crop. The experiment was conducted in CR Design with four replications during rabi 2012-13. Data showed no increase in grain and shoot yields by AMF inoculation with $\mathrm{Zn}, \mathrm{Cu}, \mathrm{Fe}$, Mn at different levels but increased root yield, plant height, spike length and hundred grains weight of wheat as compared with un-inoculated crop. Post-harvest soil $\mathrm{Zn}, \mathrm{Cu}, \mathrm{Fe}$ and $\mathrm{Mn}$ contents of $2,4.4,2.8$ and $2.9 \mathrm{mg} \cdot \mathrm{kg}^{-1}$, respectively were maximum in un-inoculated plants treated with $\mathrm{Zn}, \mathrm{Cu}, \mathrm{Fe}, \mathrm{Mn}$ at triple of recommended level. No increases in plant $\mathrm{P}, \mathrm{N}, \mathrm{Zn}, \mathrm{Cu}, \mathrm{Fe}$ and $\mathrm{Mn}$ uptakes were observed by the inoculation of AMF when compared with uninoculated crop. Maximum plant $\mathrm{Zn}, \mathrm{Cu}, \mathrm{Fe}$ and Mn uptakes of 160.5, 206, 1914.6 and 2653 g.ha- ${ }^{-1}$, respectively were recorded in uninoculated plants applied with $\mathrm{Zn}, \mathrm{Cu}, \mathrm{Fe}, \mathrm{Mn}$ at triple of recommended levels. Wheat roots infection intensity by AMF increased with higher AMF soil spores density. Results suggest the potential of phytoremediation of contaminated soil to be improved by the inoculation of crops with AMF.
\end{abstract}

\section{Keywords}

AM Fungi, Heavy Metals, Phytoremediation, Nutrients Uptakes and Wheat Yield

\footnotetext{
${ }^{*}$ Corresponding author.
} 


\section{Introduction}

Ecosystem has been contaminated with heavy metals due to various natural anthropogenic activities. Heavy metals, having higher specific gravity contribute to pollution of soil, air and water. Some well-known toxic metallic elements with a specific gravity more than water include $\mathrm{As}, \mathrm{Cd}, \mathrm{Fe}, \mathrm{Pb}, \mathrm{Hg}, \mathrm{Zn}, \mathrm{Cu}$ and $\mathrm{Mn}$. Heavy metals may enter the human body through food, water, air, or absorption through skin when they come in contact with human in agriculture and manufacturing, industrial or residential setting. Some of these metals are micronutrients necessary for plant growth, such as $\mathrm{Zn}, \mathrm{Cu}, \mathrm{Mn}, \mathrm{Fe}, \mathrm{Ni}$, and $\mathrm{Co}$, while other has no biological function, such as $\mathrm{Cd}, \mathrm{Pb}$ and $\mathrm{Hg}$ [1]. Arbuscular Mycorrhizal Fungi (AMF) makes a symbiotic relationship with root of higher plants and provides a direct link between soil and plant roots [2]. About 95\% of the world's plant species belong to mycorrhizal families [3]. Symbiosis of AMF occurs in almost all types of habitat and climates including disturbed soil [4]. The AM fungi are the important rhizospheric microorganism, increase root and shoot biomass and improve plant growth. It has been indicated that AMF can colonize plant roots in metal contaminated soil [5], while their effects on metal uptake by plants are conflicting. In slightly metal contaminated soil, these fungi increased shoot uptake of metals [6], while in severely contaminated soil, AM fungi reduce shoot metals concentration and protect plants against harmful effects of metals [7]. AM fungi can contribute to plant growth mostly in disturbed and heavy metals contaminated sites by increasing access of the plants relatively to immobile minerals such as $\mathrm{P}$ [8]. These fungi improve the physical properties of soil [9] and bind heavy metals into roots that restrict their translocation into shoot tissues [10]. The AM fungi colonized plants are more resistant to stresses caused by drought, salt and heavy metals. These positive effects of the fungi on the growth of plant result in an improved nutrient supply. Physico-chemical technologies used for soil remediation make the land useless and inhibit the plant growth as they remove all the biological activities. Therefore sustainable on-sites techniques need to be developed for the remediation of heavy metals [11]. Phytoremediation is the use of plants to stabilize, clean-up, low-cost environment friendly and potentially effective technology for the reclamation of polluted soils. Mycorrhizal plants play an important role both in phytostabilization and phytoextraction. Strategies used by AM fungi in phytostabilization include immobilization of metals by precipitating polyphosphate granules in the soil, compounds secreted by the fungus, adsorption to fungal cell walls, and chelation of metals inside the fungus [12]. Heavy metals cannot be degraded chemically and need to be physically immobilized or removed. Keeping in view the significance of AMF in phytoremediation of heavy metals, this research experiment was planned.

\section{Methods and Materials}

An experiment was conducted in pots under natural conditions to determine the potential of AM fungi in phytoremediation of heavy metals and effect on yield of wheat crop. The experiment was conducted in completely randomized design (CRD) during Rabi 2012-13. There were 9 treatments with four replications. The total experimental units were 36 .

The treatments combinations for the experiment were as follows;

T1: Control (No fertilizers)

T2: $\mathrm{N}, \mathrm{P}$ and $\mathrm{K}$ as basal dose

T3: $\mathrm{Zn}, \mathrm{Cu}, \mathrm{Fe}, \mathrm{Mn}$ at recommended levels

T4: $\mathrm{Zn}, \mathrm{Cu}, \mathrm{Fe}, \mathrm{Mn}$ at double of recommended levels

T5: $\mathrm{Zn}, \mathrm{Cu}, \mathrm{Fe}, \mathrm{Mn}$ at triple of recommended levels

T6: AMF inoculation

T7: Zn, $\mathrm{Cu}, \mathrm{Fe}, \mathrm{Mn}$ at recommended levels + Mycorrhiza

T8: $\mathrm{Zn}, \mathrm{Cu}, \mathrm{Fe}, \mathrm{Mn}$ at double of recommended levels + Mycorrhiza

T9: Zn, Cu, Fe, Mn at triple of recommended levels + Mycorrhiza

A basal dose of N, P and K were applied to all treatment except control at the rate of 120, 90 and $60 \mathrm{~kg} \cdot \mathrm{ha}^{-1}$, respectively. The dose of $\mathrm{N}$ was applied in the form of urea as 3 splits application. Phosphorous was applied in the form of Single super phosphates (SSP) and K as potassium sulphate at sowing time. The heavy metals Fe, $\mathrm{Cu}, \mathrm{Zn}$ and $\mathrm{Mn}$ were applied at recommended rate of 2.5, 1.0, 2.5, $1.0 \mathrm{mg} \cdot \mathrm{kg}^{-1}$ soil and double as well as triple of recommended levels, respectively. Normal recommended cultural practices were strictly followed for optimum plant growth. Surface soil was collected from research farm of the University of Agriculture Peshawar at a depth of $0-30 \mathrm{~cm}$. The collected soil was ground and sieved at less than $2 \mathrm{~mm}$ mesh. The pots were filled with 
soil at the rate of $3 \mathrm{~kg}$ soil per pot and randomized completely with one week interval to minimize the side effects. The soil was silt loam, low in organic matter, total $\mathrm{N}$ and AB-DTPA extractable P contents, alkaline in reaction, moderately calcareous and non-saline. AMF spores isolated from rhizosphere of fresh growing berseem were used as inoculum in this experiment. Total of hundred number of AMF spores extracted from $100 \mathrm{~g}$ soil were inoculated to the crop at the time of seed sowing. These spores were dominated with Glomus intaradices species of AMF. Some other species of AMF i.e. Glomus mosseae and G. fasiculatum were observed in the inoculum but in minor quantity. Initially ten seeds of wheat were sown in each pot, which were thinned to 5 plants per pot after germination. Plants were grown to maturity stage for 127 days. Plants were harvested from each pot above surface of soil. After harvest, the plant and root samples were washed with distilled water, dried, oven at $80^{\circ} \mathrm{C}-90^{\circ} \mathrm{C}$ for 48 hours until constant weight, shoot and roots dry matter yield were recorded. After harvesting the crops, soil sample were also collected from each treatment. Some of the fresh soil samples were also stored at $4^{\circ} \mathrm{C}$ for AMF spores root infection intensity determinations, while the remaining soil was dried at room temperature, ground, sieved through a $\leq 2 \mathrm{~mm}$ sieve, and packed in labeled plastic bags for laboratory analysis.

\section{Soil and Plant Analysis}

Soil samples from each treatment were analyzed for various physical and chemical properties, like soil texture [13], pH [14], total N [15] and AB-DTPA extractable P, Zn, Cu, Fe [16]. Plant N, P, Zn, Cu, Fe and Mn uptakes were calculated by the method described by Jarrel, [17] as shown in Table 1.

Data regarded grain, shoot, root dry matter yields, 100 grain weight, plant nutrient concentration, and their accumulation by plants were analyzed statistically according to the procedure given by Steel and Torrie [18] using the MSTATC package. Arbuscular mycorrhiza fungal spores were isolated from the soil by the techniques as described by Gerdeman and Nicolson, [19]. The isolated spores from the soil sample were identified as per the guideline described by Schneck and Parez [20]. Mycorrhizal infection rates in the roots of wheat were determined according to the procedure as described by Philips and Hyman [21].

\section{Results and Discussion}

An experiment was conducted in pots to determine the potential of AM fungi in phytoremediation of heavy metals and effect on yield of wheat crop.

\subsection{Wheat Yield and Yield Components}

Grains, shoot, root dry matter yield and hundred grains weight of wheat crop as affected by AMF inoculation with heavy metals are presented in Table 2. Data showed that maximum grains and dry matter yield of 4657 and $15915 \mathrm{~kg} \cdot \mathrm{ha}^{-1}$ were recorded respectively, in treatment where $\mathrm{Zn}, \mathrm{Cu}, \mathrm{Fe}, \mathrm{Mn}$ were applied at double rate of recommended level. Maximum increases in wheat grain and dry matter yield as $36 \%$ and $11 \%$, respectively were observed in treatment of $\mathrm{Zn}, \mathrm{Cu}, \mathrm{Fe}, \mathrm{Mn}$ applied at double of recommended level over control. When compared with non-inoculated crop, a decreasing trend in grain and dry matter yields of wheat was observed by AMF inoculation with $\mathrm{Zn}, \mathrm{Cu}, \mathrm{Fe}, \mathrm{Mn}$ at different level. Maximum root yield of $2.49 \mathrm{~kg} \cdot \mathrm{ha}^{-1}$ was noted in treatment of $\mathrm{Zn}, \mathrm{Cu}, \mathrm{Fe}, \mathrm{Mn}$ applied at triple of recommended level and mycorrhiza inoculation. Maximum increase in wheat root dry matter yield as $58 \%$ was observed in treatment of $\mathrm{Zn}, \mathrm{Cu}, \mathrm{Fe}, \mathrm{Mn}$ at triple of recommended level and mycorrhiza over control. When compared with uninoculated crop increasing trend in root dry matter yield of wheat was observed with AMF inoculation with $\mathrm{Zn}, \mathrm{Cu}, \mathrm{Fe}$ and $\mathrm{Mn}$ at different levels. Highest 100 grains weight of wheat as $4.85 \mathrm{~g}$ was noted in treatment of $\mathrm{Zn}, \mathrm{Cu}, \mathrm{Fe}, \mathrm{Mn}$ applied at triple of recommended level with mycorrhiza. The maximum increase in 100 grains weight as $39 \%$ was noted in treatment of $\mathrm{Zn}, \mathrm{Cu}$, $\mathrm{Fe}, \mathrm{Mn}$ applied at triple of recommended level with mycorrhiza over control. When compared with uninoculated crop increasing trend in 100 grain weight of wheat was observed by AMF inoculation with $\mathrm{Zn}, \mathrm{Cu}, \mathrm{Fe}$ and $\mathrm{Mn}$ at different levels. Sharif and Classen [22] reported that at low P supply, infection with AMF fungi significantly increased the yield of Capsicum annum L. AL-Karaki and Clark [23]. Kahiluoto et al. [24] reported higher mycorrhizal colonization and greater benefit of mycorrhizal association in flax grown on soils with low rather than intermediate initial soil fertility. Rabie [25] found that mycorrhizal inoculation significantly increased root dry weight, total lipid and chlorophyll content in wheat plant. AM fungi can contributed to plant growth, particularly 
Table 1. Physico chemical characteristics of soil under investigations.

\begin{tabular}{ccc}
\hline Properties & Units & Concentration \\
\hline Sand & $\%$ & 28.4 \\
Silt & $\%$ & 66.2 \\
Clay & $\%$ & 5.4 \\
Textural class & - & silt loam \\
pH & - & 7.56 \\
EC & & 2.76 \\
Lime & $\mathrm{dSm}^{-1}$ & 16.5 \\
OM content & $\%$ & 0.73 \\
Total N content & $\%$ & 0.08 \\
P (AB-DTPA extractable) & $\%$ & 2.25 \\
\hline
\end{tabular}

Table 2. Yield and yield components as affected by AMF with heavy metals.

\begin{tabular}{|c|c|c|c|c|}
\hline \multirow{2}{*}{ Treatments } & Grains & Shoot & Root & \multirow{2}{*}{100 grain weight (g) } \\
\hline & \multicolumn{3}{|c|}{------------yield $\left(\mathrm{mg} \cdot\right.$ pot $^{-1}$ )------------ } & \\
\hline Control (No fertilizers) & $5118 d^{*}$ & $21570 c^{*}$ & $2.4 \mathrm{f}^{*}$ & $3.5 \mathrm{e}^{*}$ \\
\hline $\mathrm{N}, \mathrm{P}$ and $\mathrm{K}$ as basal dose & 6010 bc & 22868 abc & $3.0 \mathrm{e}$ & $4.47 \mathrm{~cd}$ \\
\hline $\mathrm{Zn}, \mathrm{Cu}, \mathrm{Fe}, \mathrm{Mn}$ at recommended levels & $6590 \mathrm{ab}$ & $23260 \mathrm{ab}$ & 3.05 de & 4.67abc \\
\hline $\mathrm{Zn}, \mathrm{Cu}, \mathrm{Fe}, \mathrm{Mn}$ at double of recommended levels & 6980 a & 23870 a & $3.1 \mathrm{~d}$ & $4.69 \mathrm{abc}$ \\
\hline $\mathrm{Zn}, \mathrm{Cu}, \mathrm{Fe}, \mathrm{Mn}$ at triple of recommended levels & 6790 a & $23720 \mathrm{ab}$ & $3.2 \mathrm{~cd}$ & $4.54 \mathrm{bcd}$ \\
\hline AMF inoculation (M) & $5570 \mathrm{~cd}$ & 22550 bc & $3.2 \mathrm{~cd}$ & $4.3 \mathrm{~d}$ \\
\hline $\mathrm{Zn}, \mathrm{Cu}, \mathrm{Fe}, \mathrm{Mn}$ at recommended levels $+\mathrm{M}$ & $5730 \mathrm{~cd}$ & $23320 \mathrm{ab}$ & $3.1 \mathrm{~d}$ & $4.7 \mathrm{ab}$ \\
\hline $\mathrm{Zn}, \mathrm{Cu}, \mathrm{Fe}, \mathrm{Mn}$ at double of recommended levels $+\mathrm{M}$ & $6630 \mathrm{ab}$ & $23420 \mathrm{ab}$ & $3.4 \mathrm{~b}$ & $4.80 \mathrm{ab}$ \\
\hline $\mathrm{Zn}, \mathrm{Cu}, \mathrm{Fe}, \mathrm{Mn}$ at triple of recommended levels $+\mathrm{M}$ & $6620 \mathrm{ab}$ & $23260 \mathrm{ab}$ & $3.7 \mathrm{a}$ & $4.85 \mathrm{a}$ \\
\hline LSD $(P \leq 0.05)$ & 661.44 & 1303.1 & 0.1542 & 0.2370 \\
\hline
\end{tabular}

${ }^{*}$ Means with different letter (s) in columns are significantly different at $\mathrm{P} \leq 0.05$. Recommended levels of $\mathrm{Zn}, \mathrm{Cu}$, Fe \& Mn were applied @ 2.5, 1.0, 2.5 and $1.0 \mathrm{mg} \cdot \mathrm{kg}^{-1}$ soil, respectively.

in disturb or heavy metal contaminated sites, by increasing plant access to relatively immobile mineral such as $\mathrm{P}$ [26], improving soil texture by binding soil particles into stable aggregates that resist wind and water erosion [27].

\subsection{Post Harvest Soil Nutrients Contents}

Data regarding post harvest soil N, P, Zn, $\mathrm{Cu}, \mathrm{Fe}$ and $\mathrm{Mn}$ contents as influenced by AMF inoculation and heavy metals are presented in Table 3. Data indicated that total $\mathrm{N}$ and AB-DTPA extractable P contents of 1730, 4.78 $\mathrm{mg} \cdot \mathrm{kg}^{-1}$, respectively were recorded in the treatment of $\mathrm{N}, \mathrm{P}$ and $\mathrm{K}$ application. The AMF inoculation of wheat reduced post harvest soil $\mathrm{Zn}, \mathrm{Cu}, \mathrm{Fe}$ and $\mathrm{Mn}$ contents as compared to uninoculated crop. Maximum content of post harvest soil $\mathrm{Zn}, \mathrm{Cu}$. Fe and $\mathrm{Mn}$ as 2, 4.4, 2.8 and $2.9 \mathrm{mg} \cdot \mathrm{kg}^{-1}$ was noted in treatment of $\mathrm{Zn}, \mathrm{Cu}, \mathrm{Fe}, \mathrm{Mn}$ applied at triple of recommended levels. Mycorrhizal symbiosis increased $\mathrm{N}$ content in soil [28] and mycorrhizal symbiosis increased $\mathrm{P}$ content in soil [29]. AM broad bean plants had higher shoot and root $\mathrm{P}, \mathrm{N}$ and $\mathrm{K}$ contents than non AM plants, regardless of wastewater treatments [30]. However, both mycorrhizal and non-mycorrhizal 
Table 3. Post harvest soil N, P, Zn, Cu, Fe, Mn concentration as affected by AMF and heavy metal.

\begin{tabular}{|c|c|c|c|c|c|c|}
\hline \multirow{3}{*}{ Treatments } & \multirow{3}{*}{ Total N } & \multicolumn{5}{|c|}{ AB-DTPA Extractable } \\
\hline & & $\mathrm{P}$ & $\mathrm{Zn}$ & $\mathrm{Cu}$ & $\mathrm{Fe}$ & $\mathrm{Mn}$ \\
\hline & & \multicolumn{5}{|c|}{$\left(\mathrm{mg} \cdot \operatorname{pot}^{-1}\right)$} \\
\hline Control (No fertilizers) & $104.1 \mathrm{e}^{*}$ & $1.4 \mathrm{f}^{*}$ & $0.053 \mathrm{~g}^{*}$ & $0.072 \mathrm{f}^{*}$ & $0.32 \mathrm{~g}^{*}$ & $0.63 \mathrm{~g}^{*}$ \\
\hline $\mathrm{N}, \mathrm{P}$ and $\mathrm{K}$ as basal dose & 228.6 a & 4.9 a & $0.077 \mathrm{f}$ & $0.18 \mathrm{e}$ & $1.56 \mathrm{f}$ & $1.64 \mathrm{f}$ \\
\hline $\mathrm{Zn}, \mathrm{Cu}, \mathrm{Fe}, \mathrm{Mn}$ at recommended levels & $191.0 \mathrm{~b}$ & $2.9 \mathrm{~cd}$ & $0.134 \mathrm{bc}$ & $0.19 \mathrm{~d}$ & 1.97 e & $2.58 \mathrm{~cd}$ \\
\hline $\mathrm{Zn}, \mathrm{Cu}, \mathrm{Fe}, \mathrm{Mn}$ at double of recommended levels & $186.9 \mathrm{bc}$ & $3.1 \mathrm{c}$ & $0.149 \mathrm{~b}$ & $0.28 \mathrm{~b}$ & $2.56 \mathrm{~b}$ & $3.48 \mathrm{~b}$ \\
\hline $\mathrm{Zn}, \mathrm{Cu}, \mathrm{Fe}, \mathrm{Mn}$ at triple of recommended levels & $209.4 \mathrm{ab}$ & $4.1 \mathrm{~b}$ & $0.241 \mathrm{a}$ & $0.31 \mathrm{a}$ & $2.91 \mathrm{a}$ & $3.98 \mathrm{a}$ \\
\hline AMF inoculation & $164.6 \mathrm{~cd}$ & $2.9 \mathrm{~d}$ & $0.084 \mathrm{ef}$ & $0.14 \mathrm{e}$ & $1.82 \mathrm{e}$ & $1.85 \mathrm{ef}$ \\
\hline $\mathrm{Zn}, \mathrm{Cu}, \mathrm{Fe}, \mathrm{Mn}$ at recommended levels + Mycorrhiza & $147.8 \mathrm{~d}$ & $1.8 \mathrm{e}$ & $0.118 \mathrm{~cd}$ & $0.26 \mathrm{~b}$ & $2.19 \mathrm{~d}$ & $2.48 \mathrm{~d}$ \\
\hline $\mathrm{Zn}, \mathrm{Cu}, \mathrm{Fe}, \mathrm{Mn}$ at double of recommended levels + Mycorrhiza & $150.5 \mathrm{~d}$ & $2.6 \mathrm{~cd}$ & 0.104 de & $0.23 \mathrm{c}$ & $2.34 \mathrm{~cd}$ & $2.82 \mathrm{c}$ \\
\hline $\mathrm{Zn}, \mathrm{Cu}, \mathrm{Fe}, \mathrm{Mn}$ at triple of recommended levels + Mycorrhiza & $165.8 \mathrm{~cd}$ & $2.9 \mathrm{~d}$ & $0.133 \mathrm{bc}$ & $0.27 \mathrm{~b}$ & $2.50 \mathrm{bc}$ & $2.05 \mathrm{e}$ \\
\hline LSD $(P \leq 0.05)$ & 23.725 & 0.3845 & 8.051E-03 & 0.0491 & 0.0997 & 0.1018 \\
\hline
\end{tabular}

*Means with different letter (s) in columns are significantly different at $\mathrm{P} \leq 0.05$. Recommended levels of $\mathrm{Zn}, \mathrm{Cu}, \mathrm{Fe} \& \mathrm{Mn}$ were applied @ 2.5, 1.0, 2.5 and $1.0 \mathrm{mg} \cdot \mathrm{kg}^{-1}$ soil, respectively.

plants grown in control (unpolluted) soil had higher $\mathrm{P}, \mathrm{N}$ and $\mathrm{K}$ contents than sewage water stressed plants, particularly at higher concentrations (40\% and $60 \%$ ). Arbuscular mycorrhizal fungus enhances soil zinc and copper content [31] [32]. In some circumstances, mycorrhiza fungi protect the plant with heavy metals content [33]. Voegelin et al. [34] observed that some of heavy metals are essential to plant and are required for plant growth and development such as $\mathrm{Cu}, \mathrm{Zn}, \mathrm{Fe}$, Mo, Ni but their higher soil contents are considered a matter of concerned to society as they adversely affect the quality of soil.

\subsection{Plants Nutrients Uptakes}

Data regarding Plant $\mathrm{N}$ and $\mathrm{P}$ uptakes as influenced by AMF inoculation and heavy metals are presented in Table 4 . Data on plant $\mathrm{N}$ uptake indicated that maximum plant $\mathrm{N}$ uptake of $152.4 \mathrm{~kg} \cdot \mathrm{ha}^{-1}$ was observed in treatment in which $\mathrm{N}, \mathrm{P}$ and $\mathrm{K}$ were applied. It is evident from the data that plant $\mathrm{N}$ uptake decreased by the inoculation of AMF with $\mathrm{Zn}, \mathrm{Cu}, \mathrm{Fe}, \mathrm{Mn}$ as compared with uninoculated crops at different levels. Data showed that the highest plant $\mathrm{P}$ uptake of $3.25 \mathrm{~kg} \cdot \mathrm{ha}^{-1}$ was recorded in treatment in which $\mathrm{N}, \mathrm{P}$ and $\mathrm{K}$ were applied. Plant $\mathrm{P}$ uptake decreased by AMF inoculation with $\mathrm{Zn}, \mathrm{Cu}, \mathrm{Fe}, \mathrm{Mn}$ as compared with uninoculated crop. Data revealed that AMF inoculation with heavy metal reduced the plant uptake of $\mathrm{Zn}, \mathrm{Cu}, \mathrm{Fe}$, and $\mathrm{Mn}$ as compared to uninoculated treatment. Maximum plant Zn, Cu, Fe, and Mn uptake of 160.6, 206.0, 1941.6 and $2653.0 \mathrm{~g} \cdot \mathrm{kg}^{-1}$ was observed in treatment of $\mathrm{Zn}, \mathrm{Cu}, \mathrm{Fe}, \mathrm{Mn}$ applied at triple of recommended levels. Plant $\mathrm{Zn}, \mathrm{Cu}$, Fe and $\mathrm{Mn}$ uptake decreased by the inoculation of AMF when compared with uninoculated crops with $\mathrm{Zn}, \mathrm{Cu}$, Fe and Mn applied at different levels. These results are supported by Smith and Read [3] who studied that arbuscular mycorrhiza are one of the most prominent soil microorganisms, which expand the interface between plant and the soil environment and contribute to plant uptake of P and N [7] as well as micronutrient $\mathrm{Cu}$ and $\mathrm{Zn}$. Growing broad bean plants with AM inoculum can minimize the heavy metals toxicity and increase the growth and P uptake [30]. AM fungi supply essential nutrients to plant from the soil through uptake by extra radical hyphae [33], but the fungus may contribute a biological barrier against transfer of heavy metals to shoots [35]. In some cases AM fungi reduce excess plant uptake of trace element like Zn, Cd and Mn [36] whereas in other cases they enhance or have no effect on the uptake [37]. Tonin et al. [38] studied that the ability of AMF fungi isolated from V. calaminaria L. colonized and reduced metal uptake by Trifolium subterraneum L. Use of these fungi resulted in lower accumulation than the use of a metal tolerant AM fungus isolated from a non tolerant plant. The effects of AMF on host plants tolerance to heavy metals may depends on reduced metal uptake because of retention and immobilization in chitin or glomalin in the fungal wall [39]. 


\subsection{Soil Spores Density and Root Infection Intensity of AMF in Wheat Root}

Data in Table 5 showed significant $(\mathrm{P} \leq 0.05)$ increase of AMF soil spores density of 24 spores per $20 \mathrm{~g}$ soil and wheat root infection rates of $52.3 \%$ in treatment of AMF inoculation. There was positive correlation between soil spores density and root infection intensity of AMF (Figure 1). Bafeel [40] demonstrated that the percentages of AM infection in the root of wheat crop significantly reduced at high levels of heavy metals in the soil. AM fungi still function at low levels of heavy metals polluted soil. These results indicated that low concentrations of heavy metals in soil are not harmful to AM fungus. Vogel-Mikus et al. [5] proved the sensitivity of AM symbionts to heavy metal contaminated soil expressed as a reduction in spores germination or root colonization. Heavy metals have been reported to reduce or eliminate AM infection at their higher concentration in the soil, thus interfering with possible beneficial effects of mycorrhizal association. Zandavalli et al. [41] studied Araucaria angustifolia inoculated with Glomus clarum, found that the biomass and $\mathrm{N}$ content of A. angustifolia

Table 4. Uptake of N, P, Zn, Cu, Fe, Mn by wheat plant as influenced by inoculation of AMF with heavy metal.

\begin{tabular}{|c|c|c|c|c|c|c|}
\hline \multirow{2}{*}{ Treatments } & $\mathrm{N}$ & $\mathrm{P}$ & $\mathrm{Zn}$ & $\mathrm{Cu}$ & $\mathrm{Fe}$ & $\mathrm{Mn}$ \\
\hline & \multicolumn{2}{|c|}{ uptake $\left(\mathrm{kg} \cdot \mathrm{ha}^{-1}\right)$} & \multicolumn{4}{|c|}{ 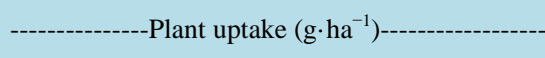 } \\
\hline Control (No fertilizers) & $69.4 \mathrm{e}^{*}$ & $0.93 \mathrm{f}^{*}$ & $35.59 \mathrm{~g}^{*}$ & $48.2 \mathrm{f}^{*}$ & $209.99 \mathrm{~g}^{*}$ & $421.77 \mathrm{~g}^{*}$ \\
\hline $\mathrm{N}, \mathrm{P}$ and $\mathrm{K}$ as basal dose & $152.4 \mathrm{a}$ & 3.25 a & $51.45 \mathrm{f}$ & $119.23 \mathrm{e}$ & $1066.0 \mathrm{f}$ & $1093.8 \mathrm{f}$ \\
\hline $\mathrm{Zn}, \mathrm{Cu}, \mathrm{Fe}, \mathrm{Mn}$ at recommended levels & $127.3 \mathrm{~b}$ & $1.96 \mathrm{~cd}$ & 89.32 bc & $129.9 \mathrm{~d}$ & 1317.0 e & $1724.5 \mathrm{~cd}$ \\
\hline $\mathrm{Zn}, \mathrm{Cu}, \mathrm{Fe}, \mathrm{Mn}$ at double of recommended levels & 124.6 bc & $2.04 \mathrm{c}$ & $99.49 \mathrm{~b}$ & $183.5 \mathrm{~b}$ & $1707.2 \mathrm{~b}$ & $2325.1 \mathrm{~b}$ \\
\hline $\mathrm{Zn}, \mathrm{Cu}, \mathrm{Fe}, \mathrm{Mn}$ at triple of recommended levels & $139.6 \mathrm{ab}$ & $2.76 \mathrm{~b}$ & $160.55 \mathrm{a}$ & 206.04 e & 1941.6 a & 2653.0 a \\
\hline AMF inoculation & $109.7 \mathrm{~cd}$ & $1.92 \mathrm{~d}$ & 59.00 ef & 95.5 e & 1215.6 e & 1235.5 ef \\
\hline $\mathrm{Zn}, \mathrm{Cu}, \mathrm{Fe}, \mathrm{Mn}$ at recommended levels + Mycorrhiza & $98.5 \mathrm{~d}$ & $1.22 \mathrm{e}$ & $79.17 \mathrm{~cd}$ & $171.8 \mathrm{~b}$ & $1457.5 \mathrm{~d}$ & $1655.8 \mathrm{~d}$ \\
\hline Zn, Cu, Fe, Mn at double of recommended levels + Mycorrhiza & $100.3 \mathrm{~d}$ & $1.74 \mathrm{~cd}$ & 69.78 de & $152.8 \mathrm{c}$ & $1559.1 \mathrm{~cd}$ & $1884.3 \mathrm{c}$ \\
\hline $\mathrm{Zn}, \mathrm{Cu}, \mathrm{Fe}, \mathrm{Mn}$ at triple of recommended levels + Mycorrhiza & $110.5 \mathrm{~cd}$ & $1.93 \mathrm{~d}$ & 88.79 bc & $183.1 \mathrm{~b}$ & $1644.9 \mathrm{bc}$ & 1367.5 e \\
\hline LSD $(P \leq 0.05)$ & 23.725 & 0.3845 & 8.051 & 0.0491 & 0.0997 & 0.1018 \\
\hline
\end{tabular}

${ }^{*}$ Means with different letter (s) in columns are significantly different at $\mathrm{P} \leq 0.05$. Recommended levels of Zn, Cu, Fe \& Mn were applied @ 2.5, 1.0, 2.5 and $1.0 \mathrm{mg} \cdot \mathrm{kg}^{-1}$ soil, respectively.

Table 5. Soil spores density of AMF and their root infection intensity in wheat as affected by AMF inoculation with heavy metals.

\begin{tabular}{lcc}
\hline \multicolumn{1}{c}{ Treatments } & AMF soil spores density/20g soil & AMF root infection intensity (\%) \\
\hline Control (No fertilizers) & $9 \mathrm{~g}^{*}$ & $16.3 \mathrm{e}^{*}$ \\
$\mathrm{~N}, \mathrm{P}$ and K as basal dose & $11 \mathrm{f}$ & $31.5 \mathrm{~d}$ \\
Zn, Cu, Fe, Mn at recommended levels & $13 \mathrm{ef}$ & $34.0 \mathrm{~d}$ \\
Zn, Cu, Fe, Mn at double of recommended levels & 14 ef & $37.7 \mathrm{~cd}$ \\
Zn, Cu, Fe, Mn at triple of recommended levels & $15 \mathrm{de}$ & $50.0 \mathrm{ab}$ \\
$\mathrm{AMF}$ inoculation & $24 \mathrm{a}$ & $52.3 \mathrm{a}$ \\
$\mathrm{Zn}, \mathrm{Cu}, \mathrm{Fe}, \mathrm{Mn}$ at recommended levels + Mycorrhiza & $17 \mathrm{~cd}$ & $48.7 \mathrm{ab}$ \\
$\mathrm{Zn}, \mathrm{Cu}, \mathrm{Fe}, \mathrm{Mn}$ at double of recommended levels + Mycorrhiza & $19 \mathrm{~b}$ & $46.7 \mathrm{~b}$ \\
$\mathrm{Zn}, \mathrm{Cu}, \mathrm{Fe}, \mathrm{Mn}$ at triple of recommended levels + Mycorrhiza & $18 \mathrm{bc}$ & $41.2 \mathrm{c}$ \\
$\mathbf{L S D}(\mathbf{P} \leq \mathbf{0 . 0 5})$ & 1.2784 & 2.3144 \\
\hline
\end{tabular}

${ }^{*}$ Means with different letter (s) in columns are significantly different at $\mathrm{P} \leq 0.05$. Recommended levels of $\mathrm{Zn}, \mathrm{Cu}, \mathrm{Fe} \& \mathrm{Mn}$ were applied @ 2.5, 1.0, 2.5 and $1.0 \mathrm{mg} \cdot \mathrm{kg}^{-1}$ soil, respectively. 


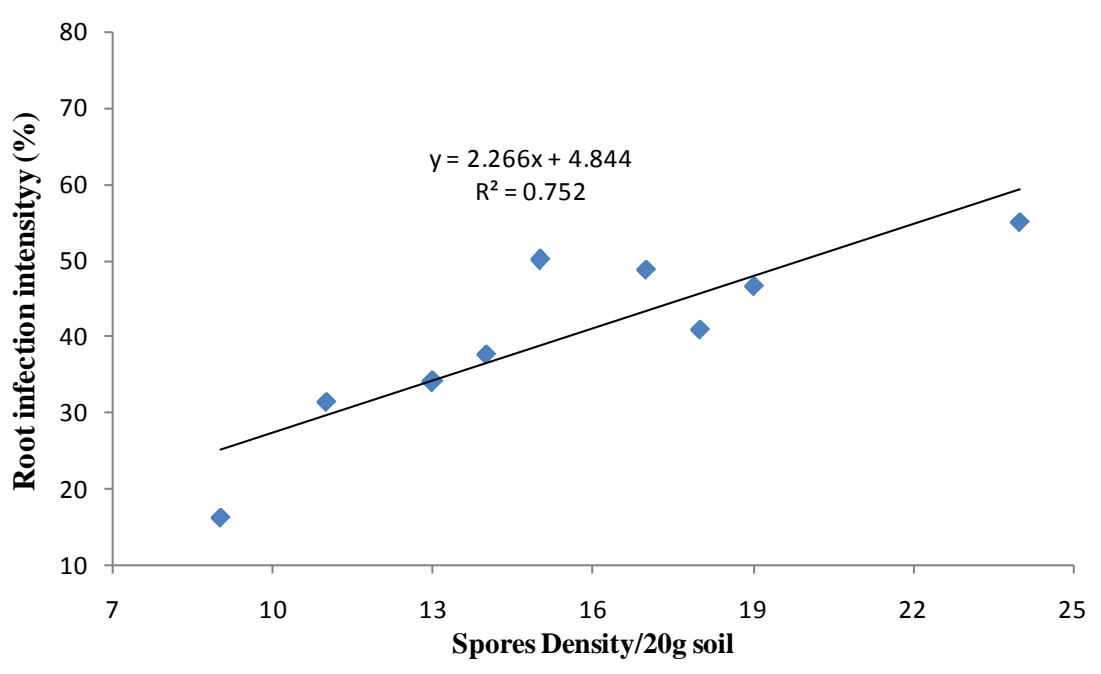

Figure 1. Relationships between soil spores density of AMF and their roots infection intensity in wheat.

forming AM increased significantly. Arbuscular mycorrhizal fungi may serve as a filtration barrier against transfer of heavy metals to plant through chelation of metals inside the fungus and secretion of various organic compounds by the fungus. These fungi establish mutual symbiosis higher plants, providing a direct physical link between soil and plant roots [2]. Some reports indicated higher concentrations of heavy metals in plant due to AM [35] whereas, other found a reduce plant concentration; i.e. $\mathrm{Zn}$ and $\mathrm{Cu}$ in mycorrhizal plant [42]. AM fungi are important as they play a vital role in metal tolerance and accumulation [43].

\section{Conclusion}

Phytoremediation is the use of plants to remediate or clean up contaminated soils to remove or stabilize heavy metals. AM fungi are important as they play a vital role in metal tolerance and accumulation. It could be concluded from the results of conducted research work that wheat grains, total dry matter yield and plant nutrients uptakes of AMF inoculated crop did not show increases over uninoculated crop with increasing levels of heavy metals. While wheat roots yield, plant height, spike length and 100 grain weight increased by the inoculation of AMF with heavy metals at different levels. Post harvest soil nutrients contents of uninoculated wheat crop were higher over AMF inoculated crop. Positive correlation was observed between soil spores density of AMF with their root infection intensity in wheat crop.

\section{Acknowledgements}

The authors would like to acknowledge Agricultural Linkage Program (ALP) of Pakistan, Agricultural Research Council (PARC) Islamabad for financial support of this study.

\section{References}

[1] Marschner, H. and Römheld, V. (1994) Strategies of Plants for Acquisition of Iron. Plant and Soil, 165, 261-274. http://dx.doi.org/10.1007/BF00008069

[2] Barea, J.M. and Jeffries, P. (1995) Arbuscular mycorrhizas in Sustainable Soil-Plant Systems. In: Varma, A. and Hock, B., Eds., Mycorrhiza, Springer, Berlin, Heidelberg, 521-560. http://dx.doi.org/10.1007/978-3-662-08897-5_23

[3] Smith, S.E. and Read, D.J. (1997) Mycorrhizal Symbiosis. Elsevier Science, Amsterdam.

[4] Barea, J.M., Azcón-Aguilar, C. and Azcon, R. (1997) Interactions between Mycorrhizal Fungi and Rhizosphere Microorganisms within the Context of Sustainable Soil-Plant Systems. In: Gange, A.C. and Brown, V.K., Eds., Multitrophic Inter-Actions in Terrestrial Systems, Blackwell Science, Cambridge, 65-77.

[5] Vogel-Mikuš, K., Drobne, D. and Regvar, M. (2005) Zn, Cd and Pb Accumulation and Arbuscular Mycorrhizal Colonisation of Pennycress Thlaspi praecox Wulf. (Brassicaceae) from the Vicinity of a Lead Mine and Smelter in Slovenia. Environmental Pollution, 133, 233-242. http://dx.doi.org/10.1016/j.envpol.2004.06.021 
[6] Weissenhorn, I., Leyval, C., Belgy, G. and Berthelin, J. (1995) Arbuscular Mycorrhizal Contribution to Heavy Metal Uptake by Maize (Zea mays L.) in Pot Culture with Contaminated Soil. Mycorrhiza, 5, 245-251.

[7] Li, X.L., George, E. and Marschner, H. (1991) Extension of the Phosphorus Depletion Zone in VA-Mycorrhizal White Clover in a Calcareous Soil. Plant and Soil, 136, 41-48. http://dx.doi.org/10.1007/BF02465218

[8] Yao, Q., Li, X., Ai, W. and Christie, P. (2003) Bi-Directional Transfer of Phosphorus between Red Clover and Perennial Ryegrass via Arbuscular Mycorrhizal Hyphal links. European Journal of Soil Biology, 39, 47-54. http://dx.doi.org/10.1016/S1164-5563(02)00008-0

[9] Steinberg, P.D. and Rillig, M.C. (2003) Differential Decomposition of Arbuscular Mycorrhizal Fungal Hyphae and Glomalin. Soil Biology and Biochemistry, 35, 191-194. http://dx.doi.org/10.1016/S0038-0717(02)00249-3

[10] Dehn, B. and Schüepp, H. (1990) Influence of VA Mycorrhizae on the Uptake and Distribution of Heavy Metals in Plants. Agriculture, Ecosystems \& Environment, 29, 79-83. http://dx.doi.org/10.1016/0167-8809(90)90258-F

[11] Zak, J.C. and Parkinson, D. (1982) Initial Vesicular-Arbuscular Mycorrhizal Development of Slender Wheatgrass on Two Amended Mine Spoils. Canadian Journal of Botany, 60, 2241-2248. http://dx.doi.org/10.1139/b82-275

[12] Javaid, A. (2011) Importance of Arbuscular Mycorrhizal Fungi in Phytoremediation of Heavy Metal Contaminated Soils. In: Khan, M.S., Ed., Biomanagement of Metal-Contaminated Soils, Springer, Berlin, Heidelberg, 125-141.

[13] Koehler, F.E., Moudre, C.D. and McNeal, B.L. (1984) Laboratory Manual for Soil Fertility. Washington State University, Pulman.

[14] Mclean, E.O. (1982) Soil pH and Lime Requirement. In: Page, A.L., Ed., Methods of Soil Analysis. Part 2. Chemical and Microbiological Properties, American Society of Agronomy, Soil Science Society of America, Madison, 199-224.

[15] Bremner, J.M. and Mulvaney, C.S. (1982) Nitrogen-Total. In: Page, A.L., Ed., Methods of Soil Analysis. Part 2. Chemical and Microbiological Properties, American Society of Agronomy, Soil Science Society of America, Madison, 595-624.

[16] Soltanpour, P.N. and Schwab, A.P. (1977) A New Soil Test for Simultaneous Extraction of Macro- and Micro-Nutrients in Alkaline Soils 1. Communications in Soil Science \& Plant Analysis, 8, 195-207. http://dx.doi.org/10.1080/00103627709366714

[17] Jarrell, W.M. and Beverly, R.B. (1981) The Dilution Effect in Plant Nutrition Studies. In: Brady, N.C., Ed., Advances in Agronomy, Academic Press, Waltham, 197-224.

[18] Steel, R.G.D. and Torrie, J.H. (1980) Principles and Procedures of Statistics, a Biometrical Approach. McGraw-Hill Kogakusha, Ltd., Tokyo.

[19] Gerdemann, J.W. and Nicolson, T.H. (1963) Spores of Mycorrhizal Endogone Species Extracted from Soil by Wet Sieving and Decanting. Transactions of the British Mycological Society, 46, 235-244. http://dx.doi.org/10.1016/S0007-1536(63)80079-0

[20] Schenck, N.C. and Perez, Y. (1990) Manual for Identification of Vesicular Arbuscular Mycorrhizal Fungi. (INVAM). University of Florida, Gainesville.

[21] Phillips, J.M. and Hayman, D.S. (1970) Improved Procedures for Clearing Roots and Staining Parasitic and Vesicular-Arbuscular Mycorrhizal Fungi for Rapid Assessment of Infection. Transactions of the British Mycological Society, 55, 158-161. http://dx.doi.org/10.1016/S0007-1536(63)80079-0

[22] Sharif, M. and Claassen, N. (2011) Action Mechanisms of Arbuscular Mycorrhizal Fungi in Phosphorus Uptake by Capsicum annuum L. Pedosphere, 21, 502-511. http://dx.doi.org/10.1016/S0007-1536(63)80079-0

[23] Al-Karaki, G.N. and Clark, R.B. (1999) Mycorrhizal Influence on Protein and Lipid of Durum Wheat Grown at Different Soil Phosphorus Levels. Mycorrhiza, 9, 97-101. http://dx.doi.org/10.1007/s005720050006

[24] Kahiluoto, H., Ketoja, E. and Vestberg, M. (2000) Promotion of Utilization of Arbuscular Mycorrhiza through Reduced P Fertilization 1. Bioassays in a Growth Chamber. Plant and Soil, 227, 191-206. http://dx.doi.org/10.1023/A:1026555717663

[25] Rabie, G.H. (2005) Role of Arbuscular Mycorrhizal Fungi in Phytoremediation of Soil Rhizosphere Spiked with Poly Aromatic Hydrocarbons. Mycobiology, 33, 41-50. http://dx.doi.org/10.4489/MYCO.2005.33.1.041

[26] Vivas, A., Vörös, A., Biró, B., Barea, J.M., Ruiz-Lozano, J.M. and Azcón, R. (2003) Beneficial Effects of Indigenous Cd-Tolerant and Cd-Sensitive Glomus mosseae Associated with a Cd-Adapted Strain of Brevibacillus sp. in Improving Plant Tolerance to Cd Contamination. Applied Soil Ecology, 24, 177-186. http://dx.doi.org/10.1016/S0929-1393(03)00088-X

[27] Rillig, M.C. and Steinberg, P.D. (2002) Glomalin Production by an Arbuscular Mycorrhizal Fungus: A Mechanism of Habitat Modification? Soil Biology and Biochemistry, 34, 1371-1374. http://dx.doi.org/10.1016/S0038-0717(02)00060-3

[28] Liu, A., Hamel, C., Elmi, A., Costa, C., Ma, B. and Smith, D.L. (2002) Concentrations of K, Ca and Mg in Maize Co- 
lonized by Arbuscular Mycorrhizal Fungi under Field Conditions. Canadian Journal of Soil Science, 82, 272-278. http://dx.doi.org/10.4141/S01-022

[29] Harley, J.L. and Smith, S.E. (1983) Mycorrhizal Symbiosis. Academic Press, Inc., London.

[30] Al-Amri, S.M. (2013) The Functional Roles of Arbuscular Mycorrhizal Fungi in Improving Growth and Tolerance of Vicia faba Plants Grown in Wastewater Contaminated Soil. African Journal of Microbiology Research, 7, 4435-4442.

[31] Ross, J.P. and Harper, J.A. (1970) Effect of Endogone mycorrhiza on Soybean Yields. Phytopathology, 60, $1552-1556$. http://dx.doi.org/10.1094/Phyto-60-1552

[32] Augé, R.M. (2001) Water Relations, Drought and Vesicular-Arbuscular Mycorrhizal Symbiosis. Mycorrhiza, 11, 3-42. http://dx.doi.org/10.1007/s005720100097

[33] Guo, Y., George, E. and Marschner, H. (1996) Contribution of an Arbuscular Mycorrhizal Fungus to the Uptake of Cadmium and Nickel in Bean and Maize Plants. Plant and Soil, 184, 195-205. http://dx.doi.org/10.1007/BF00010449

[34] Voegelin, A., Barmettler, K. and Kretzschmar, R. (2003) Heavy Metal Release from Contaminated Soils. Journal of Environmental Quality, 32, 865-875. http://dx.doi.org/10.2134/jeq2003.8650

[35] Joner, E.J. and Leyval, C. (1997) Uptake of ${ }^{109} \mathrm{Cd}$ by Roots and Hyphae of a Glomus mosseae/Trifolium subterraneum Mycorrhiza from Soil Amended with High and Low Concentrations of Cadmium. New Phytologist, 135, 353-360. http://dx.doi.org/10.1046/j.1469-8137.1997.00633.x

[36] Li, X. and Christie, P. (2001) Changes in Soil Solution Zn and pH and Uptake of Zn by Arbuscular Mycorrhizal Red Clover in Zn-Contaminated Soil. Chemosphere, 42, 201-207. http://dx.doi.org/10.1016/S0045-6535(00)00126-0

[37] Jamal, A., Ayub, N., Usman, M. and Khan, A.G. (2002) Arbuscular Mycorrhizal Fungi Enhance Zinc and Nickel Uptake from Contaminated Soil by Soybean and Lentil. International Journal of Phytoremediation, 4, 205-221. http://dx.doi.org/10.1080/15226510208500083

[38] Tonin, C., Vandenkoornhuyse, P., Joner, E.J., Straczek, J. and Leyval, C. (2001) Assessment of Arbuscular Mycorrhizal Fungi Diversity in the Rhizosphere of Viola calaminaria and Effect of These Fungi on Heavy Metal Uptake by Clover. Mycorrhiza, 10, 161-168. http://dx.doi.org/10.1007/s005720000072

[39] Christie, P., Li, X., and Chen, B. (2004) Arbuscular Mycorrhiza Can Depress Translocation of Zinc to Shoots of Host Plants in Soils Moderately Polluted with Zinc. Plant and Soil, 261, 209-217.

http://dx.doi.org/10.1023/B:PLSO.0000035542.79345.1b

[40] Bafeel, S.O. (2008) Contribution of Mycorrhizae in Phytoremediation of Lead Contaminated Soils by Eucalyptus rostrata Plants. Journal of World Applied Sciences, 5, 490-498.

[41] Zandavalli, R.B., Dillenburg, L.R., and de Souza, P.V.D. (2004) Growth Responses of Araucaria angustifolia (Araucariaceae) to Inoculation with the Mycorrhizal Fungus Glomus clarum. Applied Soil Ecology, 25, 245-255. http://dx.doi.org/10.1016/j.apsoil.2003.09.009

[42] Heggo, A., Angle, J.S. and Chaney, R.L. (1990) Effects of Vesicular-Arbuscular Mycorrhizal Fungi on Heavy Metal Uptake by Soybeans. Soil Biology and Biochemistry, 22, 865-869. http://dx.doi.org/10.1016/0038-0717(90)90169-Z

[43] Del Val, C., Barea, J.M. and Azcon-Aguilar, C. (1999) Diversity of Arbuscular Mycorrhizal Fungus Populations in Heavy-Metal-Contaminated Soils. Applied and Environmental Microbiology, 65, 718-723. 